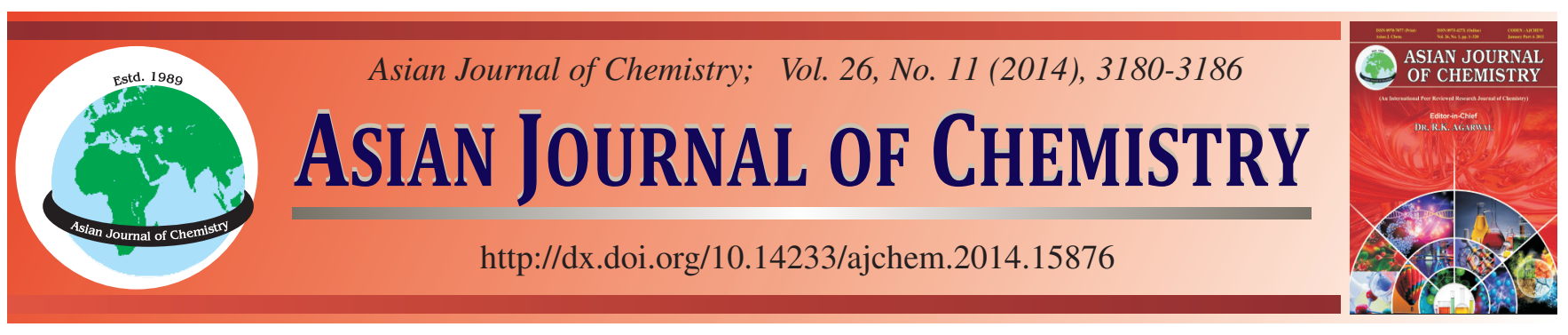

\title{
Elemental Compositions and Size Distributions of PM Between Urban and Rural Site in Beijing During the Spring of 2012
}

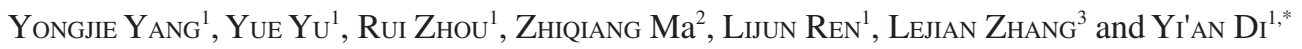

\begin{abstract}
${ }^{1}$ National Research Center for Environmental Analysis and Measurement, Beijing 100029, P.R. China ${ }^{2}$ Beijing Urban Meteorological Engineering Technology Research Center, Beijing 100089, P.R. China

${ }^{3}$ Meteorological Observation Center, China Meteorological Administration, Beijing 100081, P.R. China
\end{abstract}

*Corresponding author: E-mail: yyj800308@163.com

\begin{abstract}
Particulate matter samples were collected by Thermo Scientific Andersen impactors in order to investigate the characteristic of size distributions and elemental compositions of particulate matter between urban and rural region in Beijing. The concentrations of 23 elements including $\mathrm{Na}, \mathrm{Mg}, \mathrm{Al}, \mathrm{K}, \mathrm{Ca}, \mathrm{V}, \mathrm{Cr}, \mathrm{Mn}, \mathrm{Fe}, \mathrm{Co}, \mathrm{Ni}, \mathrm{Cu}, \mathrm{Zn}, \mathrm{As}, \mathrm{Se}, \mathrm{Sr}, \mathrm{Mo}, \mathrm{Cd}, \mathrm{Ba}, \mathrm{Tl}, \mathrm{Pb}$, Th and U were detected by ICP-MS. The results showed that the total concentration of the elements at urban site detected was $38001.5 \mathrm{ng} \mathrm{m}^{-3}$, which was 1.4 times higher than that at rural site. The concentration of pollution elements $\mathrm{Cr}, \mathrm{Ni}, \mathrm{Cu}, \mathrm{Zn}, \mathrm{As}$ and $\mathrm{Pb}$ at urban site were 71, 34, 58, 411.1, 10.2 and 202.4 $\mathrm{ng} \mathrm{m}^{-3}$ in the fine particles and 70.2, 38.6, 46.5, 298.3, 5.0 and $51.5 \mathrm{ng} \mathrm{m}^{-3}$ in the coarse particles, 1.2-2.0 times higher and 1.0-1.8 times higher than those at rural site, respectively. Then, it was found that $\mathrm{Al}, \mathrm{Ca}, \mathrm{Mg}, \mathrm{Fe}, \mathrm{Ba}$, Th and $\mathrm{Sr}$ were mainly associated with coarse particles with a peak at 4.7-5.8 $\mu \mathrm{m}, \mathrm{Cd}, \mathrm{As}, \mathrm{Tl}$ and $\mathrm{Pb}$ were found to be most dominant in fine particles with the peak at $0.43-1.1 \mu \mathrm{m}$ and $\mathrm{Na}, \mathrm{K}, \mathrm{Ni}, \mathrm{V}, \mathrm{Zn}, \mathrm{Cr}, \mathrm{Se}, \mathrm{Co}, \mathrm{Mo}, \mathrm{Cu}, \mathrm{Mn}$ and $\mathrm{U}$ had a multi-mode distribution, with peaks at 0.43 to $1.1 \mu \mathrm{m}$ and 4.7 to $5.8 \mu \mathrm{m}$. Investigation using backward air mass trajectory cluster analysis indicates that the air masses $(61.1 \%)$ reaching urban site and (59.6\%) reaching rural site originated from the south and southeast of the sites.
\end{abstract}

Keywords: Particulate matter, Size distribution, Enrichment factor.

\section{INTRODUCTION}

Atmospheric aerosols can scatter or absorb both incoming solar radiation and thermal radiation emitted from the earth's surface to directly change the radiation balance ${ }^{1-5}$. Aerosols can play as condensation nuclei for cloud droplets affecting cloud and precipitation formation and causing indirect radioactive forcing ${ }^{6}$. Anthropogenic particles in the atmosphere can lead to serious environmental problems ${ }^{7-9}$. Furthermore, aerosols can be related with serious health hazards, such as the increasing risk of respiratory diseases and other diseases, leading to a higher mortality rate ${ }^{9,10}$. Some elements are potentially toxic trace metals, such as $\mathrm{Pb}, \mathrm{Cd}, \mathrm{V}, \mathrm{Fe}, \mathrm{Zn}, \mathrm{Cr}, \mathrm{Ni}, \mathrm{Mn}$ and $\mathrm{Cu}$. Studies show that metals associated with ambient particles catalyze oxidative stress ${ }^{11,12}$ and may be responsible for production and release of inflammatory mediators by the respiratory tract epithelium, which contribute to the toxic effects of particulate air pollutants reported in epidemiological studies ${ }^{13}$.

Beijing, the capital of the P.R. China with a population of over 19 million and an area of 16, 800 square kilometers (38\% in flat land and $62 \%$ in mountains), is surrounded by high mountains to the north, south and west. The natural geogra- phical conditions along with the small environmental capacity lead to natural disadvantages with respect to the air quality in Beijing. Serious air pollution has been reported in Beijing and coal burning, vehicle emissions, secondary aerosols, dust storms, biomass open burning and crust soils have been reported responsible for the situations ${ }^{14-16}$ The particulate matter (PM), which is a higher level than the National Ambient Quality Standard ${ }^{17-19}$ is still a problem for Beijing. However, studies on the characteristic and size distributions of elements in particulate matter on different sites in Beijing are rather limited $^{20,21}$. Therefore, this study focused on the size distributions and elemental compositions of particulate matter between urban and rural site in Beijing.

\section{EXPERIMENTAL}

NERC station: Measurements were conducted at an urban site and a rural site of Beijing. The urban site, the NERC site, is on the campus of National Research Center for Environmental Analysis and Measurement in the northeast section of the Beijing city, Fig. 1. Instruments were installed, about $40 \mathrm{~m}$ above ground, on the roof of the office building of National 
Research Center for Environmental Analysis and Measurement. Surrounding the NERC site are the office and residential areas and about $50 \mathrm{~m}$ north of NERC station is the $4^{\text {th }}$ Ring Road, one of the heaviest traffic streets northeast of Beijing city.

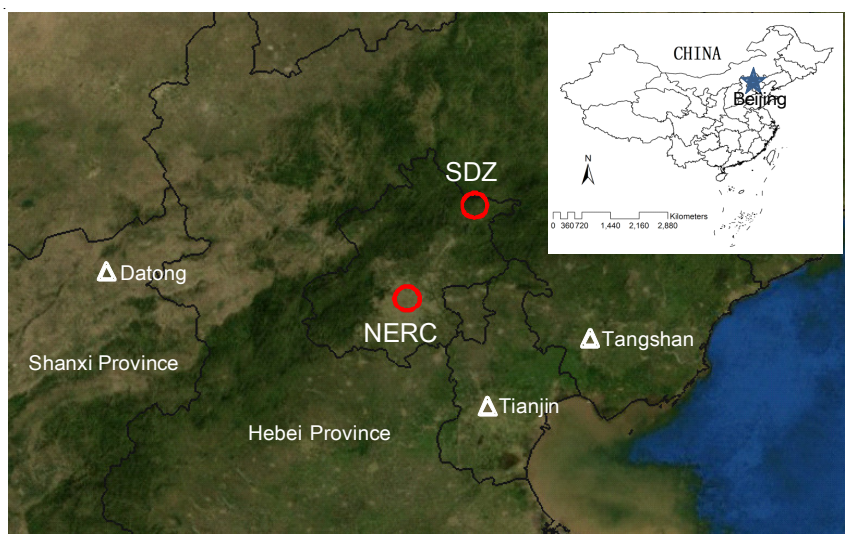

Fig. 1. Location of NERC site and SDZ site

SDZ station ${ }^{19}$ : The rural site, the SDZ site, is in the Shangdianzi Regional Background Air Pollution Monitoring Station $\left(117^{\circ} 07^{\prime} \mathrm{E}, 40^{\circ} 39^{\prime} \mathrm{N}, 293.3 \mathrm{~m}\right.$ above sea level), which is the WMO/GAW regional background station in Miyun county, a suburb of Beijing city, Fig. 1. The site is on the gentle slope of a small hill. The geography surrounding the SDZ site is characterized by rolling hills with farmland, orchard and forests. On the foot of the hill, about $2 \mathrm{~km}$ south of the site is the Shangdianzi village with about 1200 inhabitants. The major local economical activities within Miyun county are farming and fruit growing.

Sampling: At both sites, 252 samples were collected with an eight-stage low pressure impactor (Thermo Scientific Andersen, USA) from April 9 to April 23 of 2012. Mixed cellulose ester filter substrates (Thermo-Electron Corporation, USA) were employed in all stages and a flow rate of 28.3 $\mathrm{L} / \mathrm{min}$ was used. The $50 \%$ cut off diameters (D 50) were 9.0, $5.8,4.7,3.3,2.1,1.1,0.65$ and $0.43 \mu \mathrm{m}$. The sampling time was $24 \mathrm{~h}$ (from 9:00 am to 9:00 am of the following day). After sampling, the filters were individually placed into plastic bags and into a freezer $\left(-20^{\circ} \mathrm{C}\right)$ until the transport and subsequent analysis.

The method applied chemical analysis has been described by Yongjie et $a l^{22}$. Briefly, the remaining half of each cellulose ester filter was digested in closed vessel containing $2 \mathrm{~mL}$ of $\mathrm{H}_{2} \mathrm{O}_{2}, 6 \mathrm{~mL} \mathrm{HNO}_{3}$ and $0.1 \mathrm{~mL}$ of $\mathrm{HF}$ in $180^{\circ} \mathrm{C}$ for $6 \mathrm{~h}$. Then the concentrations of 23 elements including $\mathrm{Na}, \mathrm{Mg}, \mathrm{Al}, \mathrm{K}$, $\mathrm{Ca}, \mathrm{V}, \mathrm{Cr}, \mathrm{Mn}, \mathrm{Fe}, \mathrm{Co}, \mathrm{Ni}, \mathrm{Cu}, \mathrm{Zn}, \mathrm{As}, \mathrm{Se}, \mathrm{Sr}, \mathrm{Mo}, \mathrm{Cd}, \mathrm{Ba}, \mathrm{Tl}$, $\mathrm{Pb}$, Th and $\mathrm{U}$ were analyzed by inductively coupled plasma mass spectrometry (ICP-MS, 7700 $\mathrm{x}$, Agilent). Quantification was performing using the external calibration technique with a set of external calibration standards at concentration levels close to those of the samples. Procedural and field blanks were also determined and these values were subtracted from the measured sample concentrations. The blanks were taken every 9 samples.

Meterological data: An automatic weather station was placed 10 meters away near the samplers. Meterological parameters (Table-1), including air temperature, wind speed, air pressure and relative humidity were measured simultaneously.

\section{RESULTS AND DISCUSSION}

Aerosol composition: Mean elemental compositions of particulate matter collected at NERC site and SDZ site are given in Table-2. It is defined that particles with aerodynamic diameters more than $2.1 \mu \mathrm{m}$ are coarse particles and those with aerodynamic diameters less than $2.1 \mu \mathrm{m}$ are fine particles in this study. The total elements detected in the fine particles occupied $17.2 \%$ and $23.1 \%$ at NERC and SDZ. The concentrations of $\mathrm{Na}, \mathrm{Mg}, \mathrm{Al}, \mathrm{K}, \mathrm{Ca}$ and $\mathrm{Fe}$ constituted the major proportion in the measurements of particulate matter, occupying 95.5 and $95.6 \%$ of all the elements which were detected at NERC and SDZ. Calcium showed highest concentration at $11512.7 \mathrm{ng} \mathrm{m}^{-3}$ at NERC and $\mathrm{Al}$ showed highest concentration at $6270.5 \mathrm{ng} \mathrm{m}^{-3}$ at SDZ. For $\mathrm{Na}, \mathrm{Mg}, \mathrm{Al}, \mathrm{K}, \mathrm{Ca}$ and $\mathrm{Fe}$, high concentrations are not surprising, because they are commonly found in the crustal origin elements, which constitute the major proportion in the measurements of particulate matter. The concentration of pollution elements such as $\mathrm{Cr}, \mathrm{Ni}, \mathrm{Cu}, \mathrm{Zn}, \mathrm{As}$ and $\mathrm{Pb}$ occupied $3.4 \%$ of all the elements in particulate matter at both NERC and SDZ.

The difference of elemental concentrations between NERC and SDZ is also shown in Table-2. Higher concentrations of both crustal and pollution elements of particulate matter except $\mathrm{Al}$ at NERC were observed than those at SDZ. The total concentration of the elements at NERC detected in this study was 1.4 times higher than that at SDZ. The concentration of crustal elements in particulate matter, $\mathrm{Na}, \mathrm{Mg}, \mathrm{Ca}, \mathrm{Fe}, \mathrm{Sr}, \mathrm{U}$, Th and $\mathrm{Ba}$ at NERC were 1 to 2 times higher than those at $\mathrm{SDZ}$. The concentration of pollution elements $\mathrm{Cr}, \mathrm{Ni}, \mathrm{Cu}, \mathrm{Zn}$, $\mathrm{As}$ and $\mathrm{Pb}$ at NERC were 71.0, 34.0, 58.0, 411.1, 10.2 and $202.4 \mathrm{ng} \mathrm{m}^{-3}$ in the fine particles and 70.2, 38.6, 46.5, 298.3, 5.0 and $51.5 \mathrm{ng} \mathrm{m}^{-3}$ in the coarse particles, respectively; $1.2-$ 2.0 times higher and 1.0-1.8 times higher than those at SDZ. Although they were little lower than those of NERC, the elemental concentrations of SDZ still remain high level. Because the site is located on the rural region, only minimal natural and anthropogenic pollution sources are within a $30 \mathrm{-km}$ radius surrounding the SDZ site. Aerosols can strongly affected from the Beijing-Tianjin-Hebei region by long-distance transportation.

Size distribution of elements: The size distributions of the individual elements at NERC and SDZ are presented in Fig. 2. The elements can be roughly divided into three groups based on particle size distribution. Group 1 elements are mostly

TABLE-1

METEOROLOGICAL INFORMATION DURING THE SAMPLING PERIOD

\begin{tabular}{ccccc}
\hline & Relative humidity $(\%)$ & Air pressure $(\mathrm{mPa})$ & Wind speed $(\mathrm{m} / \mathrm{s})$ & Temperature $\left({ }^{\circ} \mathrm{C}\right)$ \\
\hline SDZ & 48 & 975.3 & 3.7 & 16.2 \\
NERC & 49 & 1005.6 & 4.6 & 18.0 \\
\hline
\end{tabular}


TABLE-2

ELEMENT CONCENTRATIONS OF PARTICULATE MATTER AT NERC SITE AND SDZ SITE IN APRIL 2012 (ng mº

\begin{tabular}{|c|c|c|c|c|c|c|}
\hline \multirow{2}{*}{ Element } & \multicolumn{3}{|c|}{ NERC } & \multicolumn{3}{|c|}{ SDZ } \\
\hline & Fine & Coarse & Total & Fine & Coarse & Total \\
\hline $\mathrm{Na}$ & $1293.8 \pm 471.6$ & $2784.8 \pm 607.6$ & $4078.6 \pm 918.9$ & $1531.4 \pm 660.9$ & $2541.0 \pm 749.4$ & $4072.4 \pm 1287.6$ \\
\hline $\mathrm{Mg}$ & $363.1 \pm 118.0$ & $3187.6 \pm 1141.7$ & $3550.7 \pm 1182.3$ & $317.0 \pm 195.3$ & $1650.0 \pm 754.2$ & $1967.0 \pm 884.4$ \\
\hline $\mathrm{Al}$ & $529.0 \pm 269.0$ & $5429.7 \pm 2415.2$ & $5958.7 \pm 2510.1$ & $693.1 \pm 419.9$ & $5577.4 \pm 2950.2$ & $6270.5 \pm 3280.7$ \\
\hline K & $1175.6 \pm 742.6$ & $1924.0 \pm 771.8$ & $3099.6 \pm 842.7$ & $836.7 \pm 660.6$ & $968.9 \pm 484.7$ & $1805.6 \pm 982.4$ \\
\hline $\mathrm{Ca}$ & $779.8 \pm 361.3$ & $10732.9 \pm 4086.3$ & $11512.7 \pm 4150.7$ & $714.0 \pm 589.0$ & $5006.9 \pm 3290.5$ & $5720.9 \pm 3630.7$ \\
\hline $\mathrm{V}$ & $4.1 \pm 2.5$ & $12.6 \pm 4.2$ & $16.7 \pm 4.2$ & $3.5 \pm 2.3$ & $7.1 \pm 3.7$ & $10.6 \pm 5.5$ \\
\hline $\mathrm{Cr}$ & $71.0 \pm 34.7$ & $70.2 \pm 35.8$ & $141.2 \pm 64.8$ & $57.3 \pm 29.9$ & $69.0 \pm 33.3$ & $126.3 \pm 51.3$ \\
\hline $\mathrm{Mn}$ & $65.5 \pm 24.1$ & $135.6 \pm 39.8$ & $201.1 \pm 44.3$ & $48.0 \pm 25.0$ & $77.8 \pm 33.8$ & $125.8 \pm 55.8$ \\
\hline $\mathrm{Fe}$ & $1509.6 \pm 823.4$ & $6572.2 \pm 1652.2$ & $8081.8 \pm 2112.6$ & $1447.5 \pm 930.5$ & $4061.1 \pm 1983.9$ & $5508.6 \pm 2677.0$ \\
\hline Co & $1.5 \pm 0.5$ & $3.4 \pm 0.9$ & $4.9 \pm 1.3$ & $1.7 \pm 0.9$ & $2.9 \pm 1.2$ & $4.6 \pm 1.8$ \\
\hline $\mathrm{Ni}$ & $34.0 \pm 20.6$ & $38.6 \pm 22.7$ & $72.6 \pm 41.8$ & $26.0 \pm 18.0$ & $32.3 \pm 15.7$ & $58.3 \pm 30.2$ \\
\hline $\mathrm{Cu}$ & $58.0 \pm 43.7$ & $46.5 \pm 15.4$ & $104.5 \pm 53.2$ & $39.5 \pm 28.6$ & $36.5 \pm 33.2$ & $76.0 \pm 61.4$ \\
\hline $\mathrm{Zn}$ & $411.1 \pm 174.8$ & $298.3 \pm 196.4$ & $709.4 \pm 289.0$ & $204.0 \pm 150.8$ & $229.1 \pm 245.4$ & $433.1 \pm 362.7$ \\
\hline $\mathrm{Sr}$ & $4.7 \pm 2.3$ & $51.6 \pm 20.8$ & $56.3 \pm 21.8$ & $6.1 \pm 4.9$ & $26.1 \pm 14.5$ & $32.2 \pm 18.1$ \\
\hline Mo & $2.6 \pm 0.6$ & $2.8 \pm 0.6$ & $5.4 \pm 1.0$ & $2.6 \pm 1.6$ & $2.4 \pm 1.7$ & $5.0 \pm 3.1$ \\
\hline $\mathrm{Cd}$ & $2.8 \pm 1.7$ & $1.0 \pm 0.5$ & $3.8 \pm 1.9$ & $1.9 \pm 1.3$ & $0.8 \pm 0.8$ & $2.7 \pm 1.9$ \\
\hline $\mathrm{Ba}$ & $14.6 \pm 15.8$ & $108.9 \pm 43.3$ & $123.5 \pm 44.8$ & $10.3 \pm 6.0$ & $56.4 \pm 26.8$ & $66.7 \pm 31.3$ \\
\hline $\mathrm{Tl}$ & $1.9 \pm 1.0$ & $0.3 \pm 0.1$ & $2.2 \pm 1.1$ & $1.1 \pm 1.0$ & $0.2 \pm 0.2$ & $1.3 \pm 1.1$ \\
\hline $\mathrm{Pb}$ & $202.4 \pm 151.8$ & $51.5 \pm 18.3$ & $253.9 \pm 166.1$ & $164.2 \pm 141.7$ & $34.1 \pm 28.0$ & $198.3 \pm 154.6$ \\
\hline $\mathrm{Th}$ & $0.3 \pm 0.4$ & $1.7 \pm 0.7$ & $2.0 \pm 0.9$ & $0.2 \pm 0.3$ & $0.9 \pm 0.6$ & $1.1 \pm 0.6$ \\
\hline $\mathrm{U}$ & $0.3 \pm 0.2$ & $0.6 \pm 0.3$ & $0.9 \pm 0.5$ & $0.2 \pm 0.2$ & $0.3 \pm 0.3$ & $0.5 \pm 0.4$ \\
\hline$\Sigma$ & $6540.1 \pm 2178.0$ & $31461.4 \pm 10059.2$ & $38001.5 \pm 10021.5$ & $6115.4 \pm 2525.9$ & $20384.7 \pm 9483.4$ & $26500.1 \pm 11478.1$ \\
\hline
\end{tabular}
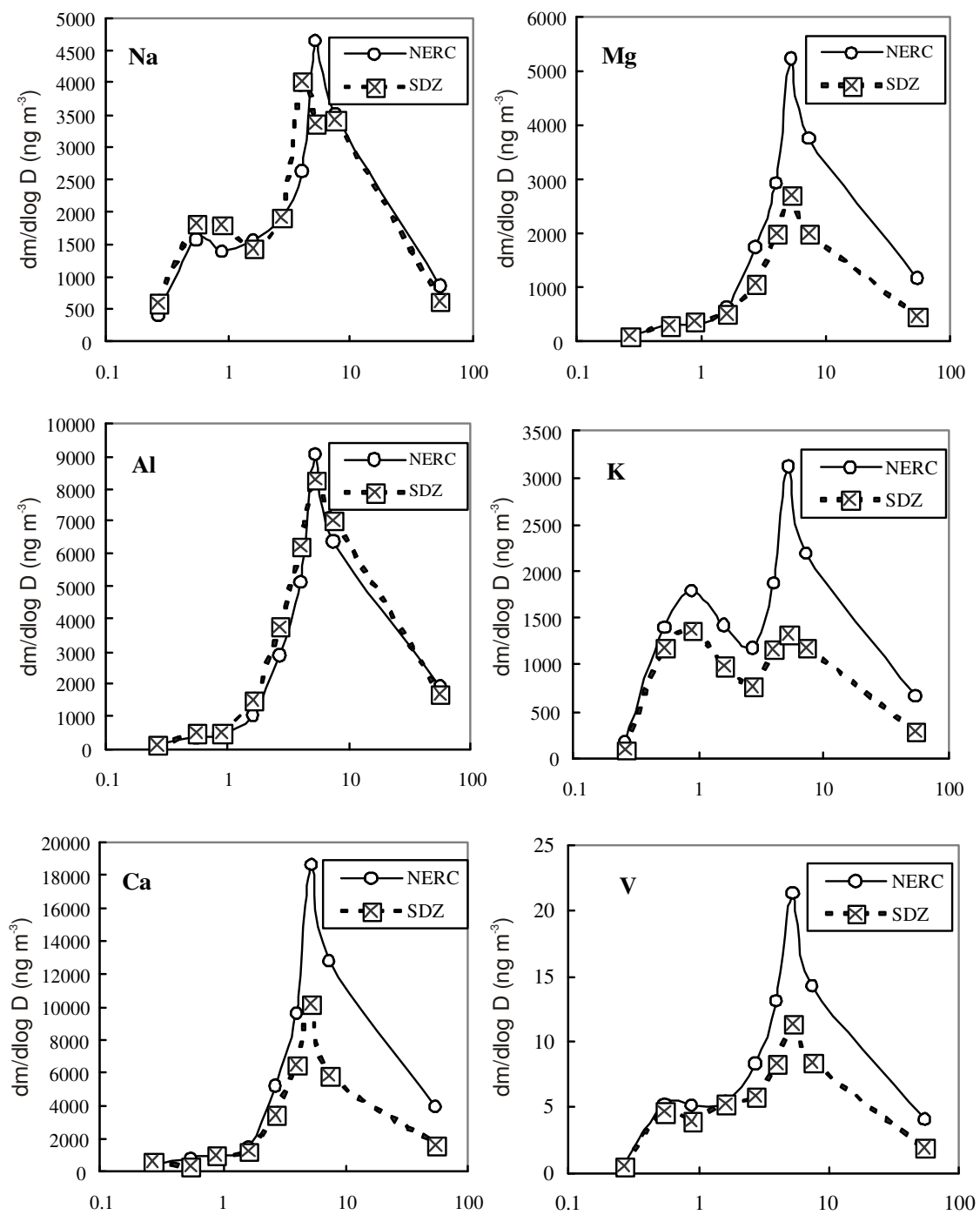
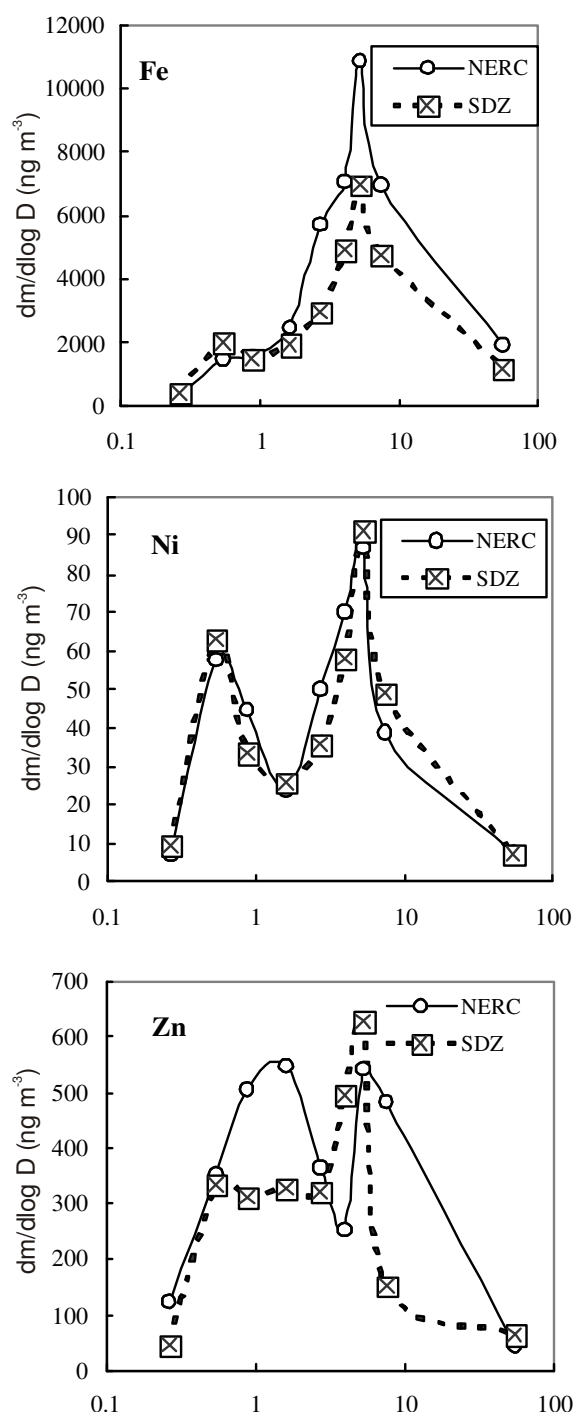

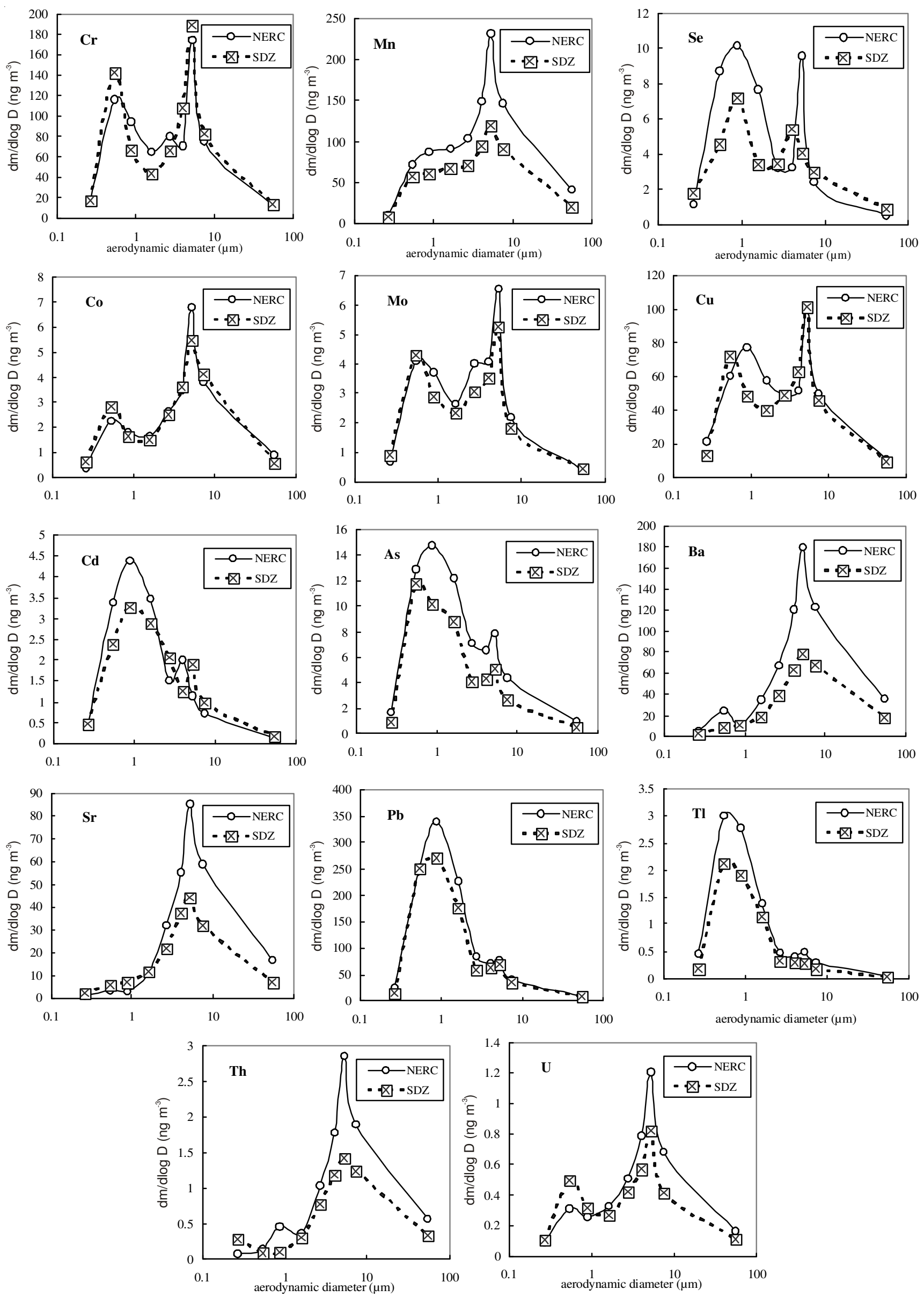

Fig. 2. Size distribution of elements at NERC and SDZ during April 2012 
concentrated in the coarse mode, with a peak at 4.7 to $5.8 \mu \mathrm{m}$, including $\mathrm{Al}, \mathrm{Ca}, \mathrm{Mg}, \mathrm{Fe}, \mathrm{Ba}$, Th and $\mathrm{Sr}$. Group 2 elements are mostly concentrated in the accumulation mode, with a peak at 0.43 to $1.1 \mu \mathrm{m}$, including $\mathrm{Cd}$, $\mathrm{As}, \mathrm{Tl}$ and $\mathrm{Pb}$. Group 3 elements have a multi-mode distribution, with peaks at 0.43 to $1.1 \mu \mathrm{m}$ and 4.7 to $5.8 \mu \mathrm{m}$ including $\mathrm{Na}, \mathrm{K}, \mathrm{Ni}, \mathrm{V}, \mathrm{Zn}, \mathrm{Cr}, \mathrm{Se}, \mathrm{Co}, \mathrm{Mo}$, $\mathrm{Cu}, \mathrm{Mn}$ and $\mathrm{U}$. For K, Mg, Fe, Ca, V, Mn, Ba, Sr, Th and U, the values of the peaks in the coarse mode at NERC were 1.5 (U) to $2.4(\mathrm{~K})$ times higher than those at SDZ. For Zn, Se, Cd, $\mathrm{As}, \mathrm{Pb}$ and $\mathrm{Tl}$, the values of the peaks in the accumulation mode at NERC were $1.3(\mathrm{~Pb})$ to $1.7(\mathrm{Zn})$ times higher than those at SDZ. The types of K and Zn's size distribution changed a lot between NERC and SDZ. Potassium is dominant in the accumulation mode at SDZ but it presented in the coarse mode at NERC. Zinc is dominant in the coarse mode at SDZ, but showed in the accumulation mode at NERC. Elements in the coarse mode demonstrated the contribution of nature emission sources, those in the accumulation mode demonstrated the contribution of anthropogenic emission sources ${ }^{23,24}$.

Enrichment factors: The enrichment factor $(\mathrm{EF})$ of elements in aerosols relative to the crustal material is often calculated to identify the source regions and evaluate the degree of anthropogenic influence ${ }^{25,26}$, which is defined as follows:

$$
\mathrm{EF}_{\mathrm{X}}=\left(\mathrm{C}_{\mathrm{X}} / \mathrm{C}_{\mathrm{R}}\right)_{\text {aerosol }} /\left(\mathrm{C}_{\mathrm{X}} / \mathrm{C}_{\mathrm{R}}\right) \text { crust, }
$$

where $X$ represents the element of interest; $\mathrm{EF}_{X}$ is the enrichment factor of $X ; C_{X}$ the concentration of $X$ and $C_{R}$ is the concentration of a reference element. The aerosol and crust subscripts refer to particles in the aerosol samples and crustal material, respectively. If the $\mathrm{EF}_{\mathrm{X}}$ approaches unity, the crustal source is the dominant source for the element $\mathrm{X}$, but if the $\mathrm{EF}_{\mathrm{X}}$ is $>10$, the element $\mathrm{X}$ may have a significant fraction from noncrustal sources. Aluminium was selected as the reference material for our enrichment factor calculations ${ }^{27}$. average upper continental crust composition was used as the elemental composition of the crust material.
Table- 3 shows the averages of the enrichment factors of the elements in particulate matter collected at NERC and SDZ. Totally speaking, much higher values of the enrichment factors in the accumulation mode were observed at both NERC and SDZ and relatively lower values of the enrichment factors were also observed in the coarse mode at two sites. The enrichment factors for $\mathrm{Cr}, \mathrm{Co}, \mathrm{Ni}, \mathrm{Cu}, \mathrm{Zn}, \mathrm{As}, \mathrm{Se}, \mathrm{Mo}, \mathrm{Cd}, \mathrm{Tl}$ and $\mathrm{Pb}$ in the fine particles were tens and even hundreds times higher than those in the coarse particles, which indicated that these elements mainly come from anthropogenic activities. The highest enrichment factors were that of Cd (range: 94.1-9165.9) at NERC. It may be emitted from coal combustion or from non-ferrous metal industries ${ }^{28,29}$. The enrichment factors for $\mathrm{Mg}, \mathrm{Ca}, \mathrm{Fe}$, $\mathrm{Sr}$ and $\mathrm{Ba}$ were less than 10 of all the aerodynamic diameters at both sites. It indicated that these elements mainly come from the crustal sources as crustal soil, road ash. The enrichment factors for $\mathrm{Pb}$ were still at a high level in the accumulation mode of two sites, although the use of leaded gasoline has been banned in Beijing since 1997. Besides industry emissions, motor vehicle emissions and coal burning, long-range transported dust from outside Beijing and the re-suspended soil containing the deposition of those from previously emitted leaded gasoline could be the important sources of $\mathrm{Pb}$ in Beijing ${ }^{30}$. Selenium and As were probably from coal combustion, for the average abundance of $\mathrm{Se}$ and $\mathrm{As}$ in Chinese coal ${ }^{28}$ is about 400 and 3.3 times of that of the upper continental crust. The major source of $\mathrm{Cu}$ in atmosphere particles on the globe are the combustion of fossil fuels, industrial metallurgical processes and waste incineration, while $\mathrm{Ni}$ is regarded as an indicator of emission from fuel burning and vehicular emissions ${ }^{31,32}$. Zinc may be derived from industry sources or other trafficrelated sources ${ }^{33}$.

Trajectory cluster analysis: To evaluate and compare circulation patterns, five-day back-trajectories following the $3 \mathrm{D}$ wind components were calculated at a height of $500 \mathrm{~m}$

TABLE-3

ENRICHMENT FACTORS OF DIFFERENT AERODYNAMIC DIAMETERS $(\mu \mathrm{m})$ AT NERC AND SDZ IN APRIL 2012

\begin{tabular}{|c|c|c|c|c|c|c|c|c|c|c|c|c|c|c|c|c|c|c|}
\hline \multirow{2}{*}{ 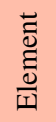 } & \multicolumn{9}{|c|}{ NERC } & \multicolumn{9}{|c|}{ SDZ } \\
\hline & $<0.43$ & $\begin{array}{c}0.43- \\
0.65\end{array}$ & $\begin{array}{c}0.65- \\
1.1\end{array}$ & $\begin{array}{l}1.1- \\
2.1\end{array}$ & $\begin{array}{c}2.1- \\
3.3\end{array}$ & $\begin{array}{l}3.3- \\
4.7\end{array}$ & $\begin{array}{c}4.7- \\
5.8\end{array}$ & $\begin{array}{c}5.8- \\
9.0\end{array}$ & $>9.0$ & $<0.43$ & $\begin{array}{c}0.43- \\
0.65\end{array}$ & $\begin{array}{c}0.65- \\
1.1\end{array}$ & $\begin{array}{l}1.1- \\
2.1\end{array}$ & $\begin{array}{l}2.1- \\
3.3\end{array}$ & $\begin{array}{l}3.3- \\
4.7\end{array}$ & $\begin{array}{c}4.7- \\
5.8\end{array}$ & $\begin{array}{c}5.8- \\
9.0\end{array}$ & $>9.0$ \\
\hline $\mathrm{Na}$ & 9.0 & 12.0 & 9.8 & 4.2 & 1.9 & 1.4 & 1.4 & 1.5 & 1.2 & 25.3 & 19.3 & 20.3 & 5.3 & 2.8 & 3.6 & 2.3 & 2.7 & 2.0 \\
\hline $\mathrm{Mg}$ & 4.3 & 5.4 & 4.8 & 3.6 & 3.6 & 3.4 & 3.5 & 3.6 & 3.6 & 5.0 & 3.5 & 4.8 & 2.0 & 1.7 & 1.9 & 2.0 & 1.7 & 1.7 \\
\hline $\mathrm{K}$ & 4.0 & 11.2 & 13.1 & 3.9 & 1.2 & 1.0 & 1.0 & 1.0 & 1.0 & 2.1 & 6.5 & 8.0 & 1.9 & 0.6 & 0.5 & 0.5 & 0.5 & 0.5 \\
\hline $\mathrm{Ca}$ & 8.2 & 5.9 & 7.0 & 3.7 & 4.8 & 5.0 & 5.5 & 5.4 & 5.4 & 12.3 & 2.0 & 5.3 & 2.3 & 2.4 & 2.8 & 3.3 & 2.2 & 2.6 \\
\hline $\mathrm{V}$ & 7.6 & 19.4 & 17.5 & 6.9 & 3.9 & 3.4 & 3.1 & 3.0 & 2.8 & 5.3 & 11.9 & 10.8 & 4.7 & 2.1 & 1.8 & 1.8 & 1.6 & 1.6 \\
\hline $\mathrm{Cr}$ & 288.5 & 738.3 & 551.3 & 144.7 & 63.4 & 31.4 & 44.0 & 27.4 & 15.2 & 606.0 & 1246.5 & 627.1 & 132.7 & 80.8 & 79.7 & 104.5 & 54.3 & 36.4 \\
\hline $\mathrm{Mn}$ & 10.9 & 26.6 & 30.1 & 11.8 & 4.8 & 3.9 & 3.4 & 3.1 & 2.9 & 8.1 & 14.7 & 16.4 & 6.0 & 2.5 & 2.0 & 1.9 & 1.7 & 1.6 \\
\hline $\mathrm{Fe}$ & 5.1 & 9.5 & 9.2 & 5.5 & 4.6 & 3.2 & 2.8 & 2.5 & 2.3 & 7.6 & 8.8 & 7.0 & 3.0 & 1.8 & 1.8 & 1.9 & 1.6 & 1.6 \\
\hline $\mathrm{Co}$ & 24.9 & 50.1 & 36.6 & 12.7 & 7.4 & 5.4 & 6.0 & 4.8 & 3.7 & 38.3 & 43.5 & 26.7 & 7.9 & 5.4 & 4.7 & 5.3 & 4.7 & 2.6 \\
\hline $\mathrm{Ni}$ & 230.1 & 641.4 & 454.7 & 91.6 & 70.0 & 28.5 & 38.6 & 24.5 & 15.3 & 553.6 & 966.8 & 545.6 & 135.8 & 76.1 & 74.7 & 88.6 & 56.5 & 34.0 \\
\hline $\mathrm{Cu}$ & 534.1 & 537.1 & 629.4 & 177.4 & 54.5 & 32.4 & 36.0 & 25.5 & 18.0 & 326.1 & 440.4 & 316.3 & 84.2 & 41.8 & 32.6 & 39.2 & 21.0 & 18.0 \\
\hline $\mathrm{Zn}$ & 1108.3 & 1106.0 & 1447.2 & 594.5 & 143.9 & 56.1 & 67.6 & 86.1 & 25.3 & 806.1 & 1448.3 & 1430.8 & 488.0 & 192.4 & 179.9 & 171.2 & 49.2 & 85.8 \\
\hline As & 716.6 & 1912.7 & 2015.6 & 628.0 & 132.8 & 68.1 & 46.7 & 36.7 & 28.0 & 355.7 & 1198.8 & 1099.6 & 311.0 & 58.2 & 37.2 & 32.6 & 20.4 & 16.0 \\
\hline $\mathrm{Sr}$ & 1.8 & 2.3 & 1.8 & 2.4 & 2.5 & 2.5 & 2.2 & 2.1 & 2.0 & 4.0 & 2.6 & 3.3 & 1.8 & 1.3 & 1.4 & 1.2 & 1.0 & 0.9 \\
\hline Mo & 298.5 & 610.2 & 506.6 & 135.9 & 74.9 & 42.3 & 38.6 & 18.5 & 11.2 & 366.1 & 438.7 & 312.6 & 82.7 & 43.4 & 30.4 & 34.0 & 13.9 & 14.0 \\
\hline $\mathrm{Cd}$ & 2943.0 & 7658.0 & 9165.9 & 2732.8 & 431.8 & 317.2 & 102.4 & 94.1 & 57.9 & 2943.9 & 3746.5 & 5419.1 & 1561.4 & 449.0 & 163.7 & 188.1 & 117.0 & 83.9 \\
\hline $\mathrm{Ba}$ & 5.7 & 10.1 & 4.2 & 4.9 & 3.4 & 3.4 & 2.9 & 2.8 & 2.7 & 3.0 & 2.5 & 3.2 & 1.8 & 1.5 & 1.5 & 1.4 & 1.4 & 1.5 \\
\hline $\mathrm{Tl}$ & 386.4 & 891.1 & 755.2 & 142.7 & 17.7 & 8.7 & 5.9 & 5.1 & 3.0 & 141.3 & 433.2 & 415.6 & 80.4 & 9.5 & 5.1 & 3.7 & 2.7 & 1.9 \\
\hline $\mathrm{Pb}$ & 786.9 & 2808.8 & 3456.7 & 876.3 & 118.5 & 54.9 & 34.4 & 26.2 & 17.8 & 477.6 & 1915.0 & 2192.0 & 466.6 & 62.7 & 40.7 & 33.4 & 20.2 & 21.9 \\
\hline Th & 4.3 & 3.0 & 8.7 & 2.6 & 2.7 & 2.6 & 2.4 & 2.2 & 2.2 & 16.0 & 1.2 & 1.5 & 1.5 & 1.5 & 1.4 & 1.3 & 1.3 & 1.4 \\
\hline $\mathrm{U}$ & 19.7 & 24.8 & 19.0 & 9.0 & 5.1 & 4.4 & 3.8 & 3.1 & 2.4 & 22.4 & 27.5 & 18.4 & 5.1 & 3.2 & 2.6 & 2.8 & 1.7 & 1.9 \\
\hline
\end{tabular}


above ground by means of the HYSPLIT4 model in isentropic coordinates, with 1-h time resolution. HYSPLIT is a well-known trajectory model, updated several times over the last two decades $^{34,35}$ and now is a complete system for computing simple trajectories for complex dispersion and deposition simulations using either puff or particle approaches. Global Data Assimilation System (GDAS) meteorological data from the US National Centers for Environmental Prediction (NCEP) were used in HYSPLIT calculations during the sampling period. The statistical method ${ }^{36}$ was used to generate clustered trajectories.

Fig. 3. displays the trajectory clusters for this study. NERC and SDZ were influenced by air masses from two main directions, the south or southeast and north or northwest. The air masses $(61.1 \%)$ reaching NERC and $(59.6 \%)$ reaching SDZ originated from the south and southeast of the sites. The sampling days were divided into two groups based on different air masses directions, which were mainly from southeast and northwest. Elemental concentrations of particulate matter from different air masses at NERC and SDZ are given in Table-4. Higher concentrations of southeast air masses, including $\mathrm{Cu}, \mathrm{Zn}, \mathrm{As}$, $\mathrm{Se}, \mathrm{Mo}, \mathrm{Cd}, \mathrm{Tl}$ and $\mathrm{Pb}$, were observed than those of northwest air masses at NERC. Lower concentrations of southeast air masses, including $\mathrm{Mg}, \mathrm{Al}, \mathrm{Sr}, \mathrm{Ba}$, Th and $\mathrm{U}$, were observed than those of northwest air masses at NERC. It has been
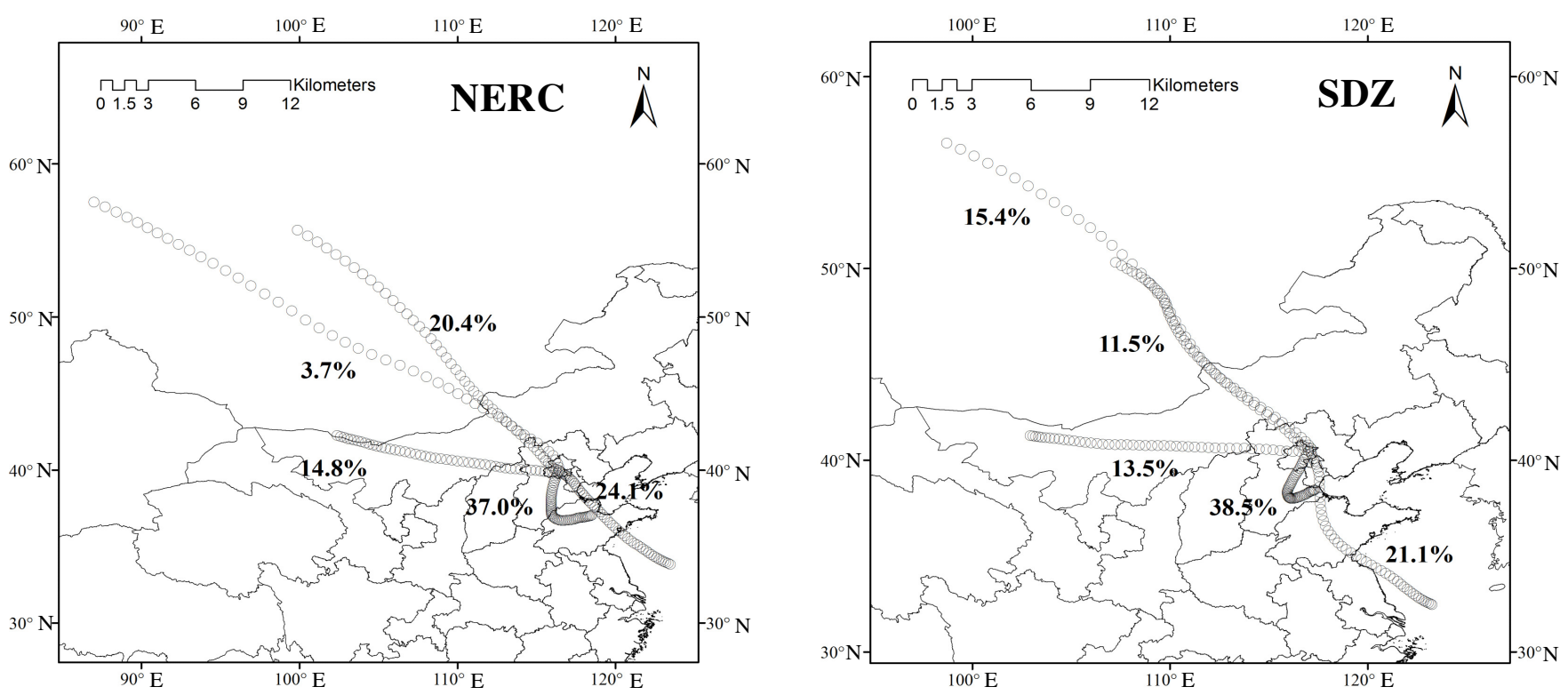

Fig. 3. Air mass backward trajectories for NERC and SDZ. Trajectory clusters are calculated based on trajectories during the sampling period. $120 \mathrm{~h}$ trajectories are shown using $1 \mathrm{~h}$ steps

TABLE-4

ELEMENTAL CONCENTRATIONS OF PARTICULATE MATTER FROM DIFFERENT AIR MASSES AT NERC AND SDZ (ng m )

\begin{tabular}{|c|c|c|c|c|c|c|}
\hline \multirow{2}{*}{ Element } & \multicolumn{3}{|c|}{ NERC } & \multicolumn{3}{|c|}{ SDZ } \\
\hline & Southeast & Northwest & $\mathrm{S} / \mathrm{N}$ & Southeast & Northwest & $\mathrm{S} / \mathrm{N}$ \\
\hline $\mathrm{Na}$ & 4100.5 & 4039.2 & 1.0 & 4263.1 & 3729.4 & 1.1 \\
\hline $\mathrm{Mg}$ & 3084.6 & 4389.5 & 0.7 & 2149.2 & 1638.9 & 1.3 \\
\hline $\mathrm{Al}$ & 5241.1 & 7249.0 & 0.7 & 6546.4 & 5773.9 & 1.1 \\
\hline $\mathrm{K}$ & 3246.7 & 2834.7 & 1.1 & 2250.0 & 1005.4 & 2.2 \\
\hline $\mathrm{Ca}$ & 10935.5 & 12551.7 & 0.9 & 6543.7 & 4239.8 & 1.5 \\
\hline $\mathrm{V}$ & 17.0 & 16.2 & 1.0 & 12.1 & 8.0 & 1.5 \\
\hline $\mathrm{Cr}$ & 139.0 & 145.5 & 1.0 & 132.3 & 115.7 & 1.1 \\
\hline $\mathrm{Mn}$ & 198.5 & 205.8 & 1.0 & 146.7 & 88.3 & 1.7 \\
\hline $\mathrm{Fe}$ & 8108.8 & 8033.4 & 1.0 & 5693.4 & 5175.8 & 1.1 \\
\hline Co & 4.8 & 5.1 & 0.9 & 5.4 & 3.2 & 1.7 \\
\hline $\mathrm{Ni}$ & 69.1 & 78.9 & 0.9 & 51.2 & 71.0 & 0.7 \\
\hline $\mathrm{Cu}$ & 110.2 & 94.2 & 1.2 & 63.7 & 98.1 & 0.6 \\
\hline $\mathrm{Zn}$ & 763.4 & 612.1 & 1.2 & 540.7 & 239.4 & 2.3 \\
\hline As & 19.0 & 8.5 & 2.2 & 13.8 & 2.9 & 4.7 \\
\hline $\mathrm{Sr}$ & 51.2 & 65.3 & 0.8 & 34.3 & 28.5 & 1.2 \\
\hline Mo & 5.8 & 4.9 & 1.2 & 6.3 & 2.9 & 2.2 \\
\hline $\mathrm{Cd}$ & 4.6 & 2.6 & 1.8 & 3.4 & 1.5 & 2.2 \\
\hline $\mathrm{Ba}$ & 113.7 & 141.3 & 0.8 & 74.1 & 53.3 & 1.4 \\
\hline $\mathrm{Tl}$ & 2.6 & 1.5 & 1.7 & 1.8 & 0.2 & 8.9 \\
\hline $\mathrm{Pb}$ & 333.5 & 110.5 & 3.0 & 265.0 & 78.2 & 3.4 \\
\hline Th & 1.8 & 2.3 & 0.8 & 1.1 & 1.0 & 1.1 \\
\hline $\mathrm{U}$ & 0.8 & 1.1 & 0.7 & 0.5 & 0.6 & 0.8 \\
\hline
\end{tabular}


reported that the air pollution is serious in the southeast of the site ${ }^{19,37}$, which favor the high concentrations of pollution elements at NERC. At SDZ, higher concentrations of southeast air masses, including $\mathrm{Mg}, \mathrm{K}, \mathrm{Ca}, \mathrm{V}, \mathrm{Mn}, \mathrm{Co}, \mathrm{Zn}, \mathrm{As}, \mathrm{Se}, \mathrm{Sr}$, $\mathrm{Mo}, \mathrm{Cd}, \mathrm{Ba}, \mathrm{Tl}$ and $\mathrm{Pb}$, were observed than those of northwest air masses. Polluted air masses from urban areas and satellite towns of Beijing can be easily transported to SDZ, while relatively clean air masses arrive from northwest directions.

\section{Conclusion}

Size distributions and compositions of aerosols collected at urban and rural sites in Beijing were preliminarily characterized. It was found that elemental concentrations at urban site were higher than those at rural site. But high elemental concentrations were still observed at both sites, especially for pollution elements such as $\mathrm{Cu}, \mathrm{Zn}, \mathrm{As}$, Se and $\mathrm{Pb}$. The enrichment factors indicated that vehicle, along with coal combustion and industry emissions may be the main sources of pollution elements. Investigation using backward air mass trajectory cluster analysis indicates that air masses at both sites come predominantly from south Hebei region and inner Mongolia region during sampling period. Therefore, the pollutants from south Hebei region, appear to be transported to favor elemental concentrations of particulate matter at both sites.

\section{ACKNOWLEDGEMENTS}

This work was financially supported by the National Natural Science Foundation of China (41105089) and Beijing Natural Science Foundation (8121002).

\section{REFERENCES}

1. S. Twomey, Atmos. Environ., 8, 1251 (1974).

2. R.J. Charlson, S.E. Schwartz, J.M. Hales, R.D. Cess, J.A. Coakley, J.E. Hansen and D.J. Hofmann, Science, 255, 423 (1992).

3. N. Bellouin, O. Boucher, J. Haywood and M.S. Reddy, Nature, 438, 1138 (2005).

4. J.M. Haywood and O. Boucher, Rev. Geophys., 38, 513 (2000).

5. P.R. Buseck, D.J. Jacob, M. Posfai, J. Li and J.R. Anderson, Int. Geol. Rev., 42, 577 (2000).

6. IPCC, Climate Change 2007: The Physical Science Basis Contribution of Working Group I to the Fourth Assessment Report of the Intergovernmental Panel on Climate Change, Cambridge University Press, Cambridge, United Kingdom and New York, NY, USA, pp. 996 (2007).

7. W.L. Chameides, H. Yu, S.C. Liu, M. Bergin, X. Zhou, L. Mearns, G. Wang, C.S. Kiang, R.D. Saylor, C. Luo, Y. Huang, A. Steiner and F. Giorgi, Proc. Natl. Acad. Sci. USA, 96, 13626 (1999).
8. D.W. Dockery, C.A. Pope, X. Xu, J.D. Spengler, J.H. Ware, M.E. Fay, B.G. Ferris Jr. and F.E. Speizer, N. Engl. J. Med., 329, 1753 (1993).

9. J. Schwartz, D.W. Dockery and L.M. Neas, J. Air Waste Manag. Assoc., 46, 927 (1996).

10. J.-T. Lee, H. Kim, Y.-C. Hong, H.-J. Kwon, J. Schwartz and D.C. Christiani, Environ. Res. Sec. A, 84, 247 (2000).

11. A.J. Ghio, J. Stonehuerner, L.A. Dailey and J.D. Carter, Inhal. Toxicol., 11, 37 (1999).

12. G. Muránszky, M. Óvári, I. Virág, P. Csiba, R. Dobai and G. Záray, Microchem. J., 98, 1 (2011).

13. J.D. Carter, A.J. Ghio, J.M. Samet and R.B. Devlin, Toxicol. Appl. Pharmacol., 146, 180 (1997).

14. I. Mori, M. Nishikawa, T. Tanimura and H. Quan, Atmos. Environ., 37, 4253 (2003).

15. Y. Sun, G. Zhuang, Y. Wang, L. Han, J. Guo, M. Dan, W. Zhang, Z. Wang and Z. Hao, Atmos. Environ., 38, 5991 (2004).

16. Y. Wang, G. Zhuang, A. Tang, H. Yuan, Y. Sun, S. Chen and A. Zheng, Atmos. Environ., 39, 3771 (2005).

17. K. He, F. Yang, Y. Ma, Q. Zhang, X. Yao, C. Chan, S. Cadle, T. Chan and P. Mulawa, Atmos. Environ., 35, 4959 (2001).

18. L.T. Wang, J. Yang, P. Zhang, X.J. Zhao, Z. Wei, F.F. Zhang, J. Su and C.C Meng, Open J. Air Pollut., 2, 47 (2013).

19. X. Zhao, X. Zhang, X. Xu, J. Xu, W. Meng and W. Pu, Atmos. Environ., 43, 2893 (2009).

20. Y. Yang, Y. Wang, W. Huang, B. Hu, T. Wen and Y. Zhao, Adv. Atmos. Sci., 27, 663 (2010).

21. J. Duan, J. Tan, S. Wang, J. Hao and F. Chai, J. Environ. Sci. (China), 24, 87 (2012).

22. Y.J. Yang, J.Q. Liu, Y. Di, Y. Yu, R. Zhou, W. Xu, X.H. Bu and Z.Q. Ma, Y.W. Li and L.J. Ren, Environ. Chem., 32, 968 (2013) (in Chinese).

23. A. Karanasiou, I. Sitaras, P. Siskos and K. Eleftheriadis, Atmos. Environ., 41, 2368 (2007).

24. E. Manoli, D. Voutsa and C. Samara, Atmos. Environ., 36, 949 (2002).

25. R.A. Duce, G.L. Hoffman and W.H. Zoller, Science, 187, 59 (1975).

26. W.H. Zoller, E.S. Gladney and R.A. Duce, Science, 183, 198 (1974).

27. S.R. Taylor and S.M. McLennan, Rev. Geophys., 33, 241 (1995).

28. J.Y. Zhao, X.Y. Tang and W.H. Huang, Coal Geol. China, 14, 5 (2002).

29. D. Voutsa and C. Samara, Atmos. Environ., 36, 3583 (2002).

30. Y. Sun, G. Zhuang, W. Zhang, Y. Wang and Y. Zhuang, Atmos. Environ., 40, 2973 (2006).

31. J.O. Nriagu and J.M. Pacyna, Nature, 333, 134 (1988).

32. J.M. Pacyna, Atmos. Environ., 18, 41 (1984).

33. W. Chueinta, P.K. Hopke and P. Paatero, Atmos. Environ., 34, 3319 (2000).

34. R.R. Draxler and G.D. Rolph, HYSPLIT (Hybrid Single-Particle Lagrangian Integrated Trajectory) Model access via NOAA ARL READY Website (http://ready.arl.noaa.gov/HYSPLIT.php), NOAA Air Resources Laboratory, Silver Spring, MD (2013).

35. G.D. Rolph, Real-time Environmental Applications and Display system (READY) Website (http://ready.arl.noaa.gov), NOAA Air Resources Laboratory, Silver Spring, MD (2013).

36. G. Tang, X. Li, Y. Wang, J. Xin and X. Ren, Atmos. Chem. Phys., 9, 8813 (2009).

37. D. Ji, Y. Wang, L. Wang, L. Chen, B. Hu, G. Tang, J. Xin, T. Song, T. Wen, Y. Sun, Y. Pan and Z. Liu, Atmos. Environ., 50, 338 (2012). 